\title{
The Determinants of Bank Regulations and Supervision on the Efficiency of Islamic Banks in MENA Regions*
}

\author{
Nor Halida Haziaton MOHD NOOR ${ }^{1}$, Mohammed Hariri BAKRI ${ }^{2}$, Wan Yusrol Rizal WAN YUSOF ${ }^{3}$, \\ Nor Raihana Asmar MOHD NOOR ${ }^{4}$, Hasni ABDULLAH ${ }^{5}$
}

Received: September 01, 2020 Revised: October 26, 2020 Accepted: November 05, 2020

\begin{abstract}
This study investigates the impact of the country's governance on the revenue efficiency in the banking sectors of 42 Islamic banks in 15 countries offering Islamic banking and financial services. Technical efficiencies of individual Islamic banks were analyzed using the Data Envelopment Analysis method. The Ordinary Least Square estimation method is employed to examine the impact of country supervision and regulation on the technical efficiency of Islamic banks. With robustness check, the study assesses the impact of bank regulations and supervision on the efficiency of Islamic banks operating in different regions. The empirical findings suggest that supervisory power, activity restrictions, and private monitoring positively influence the efficiency of Islamic banks. On the other hand, we observe a negative impact of capital requirement on Middle East and North Africa (MENA) countries. The findings indicate that supervisory power, activity restrictions, and private monitoring positively influence the efficiency of Islamic banks in Asia, but vice versa on capital requirement in MENA countries. This study will contribute to the body of knowledge by assessing the types of reforms in bank regulations and supervision that work best for Islamic banks in order to increase the level of efficiency and the level of regulations and supervision of Islamic banks.
\end{abstract}

Keywords: Supervision, Bank Regulation, Islamic Banks, Data Envelopment Analysis, MENA

JEL Classification Code: G20, G21, G28

\begin{abstract}
*Acknowledgements:
The authors thank the Faculty of Business and Management, UiTM Kelantan, UITM Shah Alam and Faculty of Technology Management and Technopreneurship, Universiti Teknikal Malaysia Melaka,Malaysia and Centre of Technopreneurship Development, Universiti Teknikal Malaysia Melaka for their support.

${ }^{1}$ First Author. Senior Lecturer, Faculty of Business and Management, UiTM Kelantan, Malaysia. Email: halley2302@yahoo.com

${ }^{2}$ Corresponding Author. Associate Professor, Faculty of Technology Management and Technopreneurship, Universiti Teknikal Malaysia, Melaka, Malaysia [Postal Address: Hang Tuah Jaya, Durian Tunggal, Melaka,76100, Malaysia] Email: hariri@utem.edu.my

${ }^{3}$ Senior Lecturer, Faculty of Business and Management, UiTM Kelantan, Malaysia.Email: wanyusrol@uitm.edu.my

${ }^{4}$ Senior Lecturer, Faculty of Business and Management, UiTM Kelantan, Malaysia. Email: raihana6791@kelantan.uitm.edu.my

${ }^{5}$ Research Fellow, Malaysian Academy of SME \& Entrepreneurship Development, UiTM Shah Alam, Malaysia.

Email: hasniabd@uitm.edu.my

(C) Copyright: The Author(s)

This is an Open Access article distributed under the terms of the Creative Commons Attribution Non-Commercial License (https://creativecommons.org/licenses/by-nc/4.0/) which permits unrestricted non-commercial use, distribution, and reproduction in any medium, provided the original work is properly cited.
\end{abstract}

\section{Introduction}

The financing activities of Islamic banking are carried out using two financing methods, namely, the profit-and-loss sharing (PLS) model and a model that involves trading on credit, with the buyer incurring debts (Idris et al., 2016). In comparison to a conventional bank, an Islamic bank offers similar products and services such as deposit accounts, various types of financing, credit cards and mortgage (Bakri et al., 2017). However, Islamic bank products are based on the concept of profit-and-loss sharing, while conventional banks are not. At a theoretical level, Islamic banks not only share the same risk as conventional banks, but Islamic banks also have to deal with a new and unique risk as a result of their unique asset and liability structure (Alam et al., 2020). According to them, this new risk exists due to the compliance with Shariah requirement such as agency risk, payment risk and delivery risk.

This study sheds light the efficiency of Islamic banks by examining the determinants of the efficiency of Islamic banks. 
We determine the technical efficiency scores of 42 Islamic banks operating in 15 countries across the MENA (Middle East and North Africa) region, then we regress the technical efficiency scores as the dependent variable against the bankspecific, country-specific variables and banking regulations and supervision variables in association with Basel II's tenet in order to determine the impact towards the efficiency of Islamic banks during year 2004-2010. To account for Basel II's pillars on bank regulations and supervision, the study uses the data from Barth et al. (2008) and World Bank database. In this study, we perform two stages of analysis: the first stage is Technical Efficiency (DEA) and Univariate Analysis, and the second stage is Multivariate Regression analysis. For estimating of efficiency, we perform the firststage analysis where we established non-parametric methods (Data Envelopment Analysis) to set up the efficiency examination, and these scores are used in static panel data models to discover the impact of regulations and supervision on the level of Islamic bank efficiency. In this study, we will calculate DEA efficiency scores by using Data Envelopment Analysis (DEA). After determining the efficiency scores of the Islamic banks, we perform second-stage analysis, which is Multivariate Regression analysis. For the sake of checking the robustness of the results, we performed similar regression models by performing an interaction between the bank regulations and supervision variables with the dummy regions and dummy country income levels.

\section{Literature Review}

The literature on Islamic banking offers research from emerging markets and less developed countries, while conventional banking literature contains reports from both developed and less developed countries. The bulk of the research shows that in the evaluation of Islamic banking performance the focus has been primarily on profitability helped by financial ratios (Ismail et al., 2017). This method has been employed by numerous researchers in their comparisons of the performances of Islamic banks and conventional banks (Samad \& Hassan, 1999; Iqbal, 2001; Haron, 2004; Hassan \& Bashir, 2005). On the other hand, this approach is hampered by the time span as well as the existence of some Islamic banks (Samad \& Hassan, 1999; Iqbal 2001).

Despite the considerable development of Islamic banking in recent years, studies on the efficiency of Islamic banks is still limited in number due to the lack of sufficient data and its short history (Yudistira, 2004; Iqbal \& Molyneux, 2005; Sufian, 2007; Bader et al., 2008). The previous studies mostly focused on the technical, pure technical and scale efficiency in the Islamic banking sectors (Isik \& Hassan. 2002; Hassan $\&$ Hussein, 2003; Yudistira, 2004). Overall, few of the studies have addressed the issues of cost, revenue and profit efficiency of Islamic banks (Yudistira, 2004; Hassan, 2005; Brown \&
Skully, 2005; Sufian et al., 2012) and the study of the impact of bank regulation towards the efficiency of Islamic banks has been carried out only (Bitar, 2015, Widarjono et al., 2020), which focus on liquidity and leverage.

Barth et al. (2004) were responsible for one of the earliest studies offering empirical evidence on each of the three pillars in relation to the Basel II capital accord. The study explored how bank regulations and supervision and bank development, performance and stability were associated, and they found that there was no relationship that was statistically significant between capital stringency, official supervisory power and bank performance and stability. In contrast, they show evidence that bank performance would be boosted if private monitoring was encouraged. Some studies maintained that there was no general agreement on what is meant by good regulations and supervision and how particular regulations impacted performance and stability of the banking sector. (Demirguc-Kunt et al., $2004)$ and Barth et al. $(2004,2006)$ provided evidence that various policies on bank performance can lead to moral hazard problems and distortions between regulated and unregulated institutions.

\section{Data and Methodology}

We gather data on 42 Islamic banks from 15 countries during the period from 2004 to 2010. The primary source of financial data is the BankScope database, while the IMF Financial Statistics (IFS) and the World Bank World Development Indicator (WDI) databases are the main source for the macroeconomic and market indicators. We retrieve the account for Basel II's pillars on bank regulations and supervision the study follows the regulations and supervision variables from Barth et al. (2004b). The data for regulations and supervision variables are provided by the World Bank through two sets of surveys, which are The World Bank Regulations and Supervision Survey (2008), to cover the data for year 2004-2007 and the World Bank Regulations and Supervision Survey (2011) to cover the data for year 2008-2010.

The advantages of this database are its wide coverage (more than 100 countries) and it also measures many aspects of the regulatory environment. The data will be pooled across the selected countries and utilize the intermediation approach with assumption that all banks will have certain amount of regulated framework and all will have to utilize capital, assets and some form of liabilities to function (Ismail et al., 2014). The data cover the period of 2004 up to 2010.

\subsection{Data Envelopment Analysis}

In this study, we will calculate DEA efficiency scores by using DEA method. Three types of scores are in estimates 
efficiency: (1) technical efficiency (TE), (2) pure technical efficiency (PTE) and (3) scale efficiency (SE). The DEA method of evaluating (in) efficiency has its basis in Farrell's (1957) work and continued by Charnes et al. (1978) and Banker et al. (1984). Charnes et al. (1978) were the first to use the term "DEA" whereby they introduced a model that had an input-oriented and assumed CRS. This method is named after the researchers Charnes and Cooper-Rhodes and is referred to as the CCR model. The DEA method permits an evaluation of the technical efficiency performance of an existing technology in relation to an ideal, best practice or frontier technology (Coelli et al., 1998) to frontier, which refers technology or production frontier that shows the most technically efficient mix of inputs and outputs. Each DMU is acquired as a maximum of a ratio of weighted outputs to weighted inputs in which the greater the outputs derived from given inputs means the more efficient is the production. The weights for the ratio are determined by restricting the ratios for all DMUs to be less than or equal to unity. Banker, Charnes and Cooper in 1984 introduced a model with variable return to scale under input orientation as an extension of the CCR model by utilising the CRS assumption. The resulting "BCC" model was employed to evaluate the efficiency of DMUs typified by variable returns to scale (VRS). Banker et al. (1984) proposed that VRS breaks down total TE into two parts. The first is TE under VRS or pure technical efficiency (PTE) and it is related to how managers are able to use DMUs' given resources. The second is SE and it means to investigate scale economies by operating at a point where the production frontier shows CRS. If the TE and PTE scores of a specific DMU are different, it indicates the presence of scale inefficiency.

\subsection{The Choice of Approach, Inputs, and Outputs Variables}

Our analysis uses a variant of the intermediation approach by following the commonly-accepted intermediation proposed by Sealey and Lindley (1977). This approach assumes that banks act as an intermediary between the borrower and depositors, which is more consistent with the function of banks. The approach views banks as financial intermediaries whose primary business is to borrow funds from depositors and lend those funds to others for profit. Berger and Humphrey (1997) state that 'this approach has been found to be more relevant for financial institutions...' Duong et al. (2020)

In this study, the banks' inputs are total deposits (X1), which include deposits from customers and other banks, fixed assets (X2), which are measured by the book value of property and capital, general and administration expenses (X3), which include total expenditures on employees such as salaries, employee benefits and reserve for retirement pay.
Table 1: Descriptive Statistics for the DEA Input and Output Variable

\begin{tabular}{|l|c|c|c|}
\hline & Mean & Median & SD \\
\hline Total Deposits & 6384.73 & 682.98 & 6807.57 \\
\hline Fixed Assets & 267.65 & 13.78 & 422.77 \\
\hline $\begin{array}{l}\text { General and Administration } \\
\text { Expenses }\end{array}$ & 74.62 & 8.68 & 90.94 \\
\hline Total Loans & 5123.83 & 494.99 & 5333.23 \\
\hline Investments & 855.05 & 128.31 & 850.43 \\
\hline
\end{tabular}

Note: All variables are reported in US\$ millions at 2011 prices. The number of observations in each year is 756 observations of 108 Islamic banks.

While the banks' outputs are loans (Y1), which include financing to customers and other banks, investments (Y2), which include income derived from investment of depositors' fund and other income from Islamic banking operations. Islamic banks do not offer loans as the conventional banks, however, the term "total loans" is a generic term used to encompass the equity financing products that the Islamic banks use. Descriptive statistics of the DEA variables are presented in Table 1.

\subsection{Multivariate Panel Regression Analysis}

In the second stage, an investigation of the possible determinants of technical efficiency scores of Islamic banks is undertaken. The modeling framework is built from the approaches suggested by Chortareas et al. (2011) and we follow the regulatory and supervision variables of Barth et al. (2008, 2013). We consider three broad categories, the characteristics of the individual banks (Bank-Specifics), the characteristic of macroeconomics (Country-Specifics), and the characteristics of banking regulations and supervision (Basel II' pillars). We incorporate Bank Specifics ${ }_{j, t}$ vector for bank-specific variables, Country Specifics, vector for country specific controls and

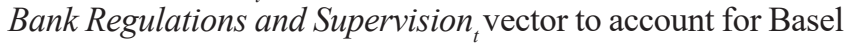
II's pillars on bank regulations and supervision variables. The variables in the vectors are as follows:

$$
\begin{aligned}
& \text { Bank Specifics }_{j, t}= \ln \left(\mathrm{SIZE}_{j, t+}+\mathrm{EQASS}_{j, t}\right. \\
&+\text { LOANSTA } \left._{j, t}+\mathrm{LNIETA}_{j, t}\right) \\
& \text { Country Specifics }_{t}=\ln \left(\mathrm{GDP}_{t}+\mathrm{INFL}_{t}+\mathrm{CR}_{t}\right. \\
&\left.+\mathrm{Z}_{t} \text { SCORE }_{t}\right) \\
& \text { Bank Regulations and Supervision }_{t}=\ln \left(\mathrm{SPOWER}_{t}\right. \\
&+\mathrm{CAPRQ}_{t} \\
&+\mathrm{PRMONIT}_{t} \\
&\left.+\mathrm{ACTRS}_{t}\right)
\end{aligned}
$$


Where, $j$ denotes bank, $t$ denotes for time period, Bank Regulations and Supervision ${ }_{t}$ denotes vector of bank regulatory, Bank Specifics ${ }_{j, t}$ denotes vector of bank-specific variables and Country Specifics denotes vector of countryspecific control variables or macroeconomic and financial markets condition. We use log-linear form for the variables similar as De Bandt and Davis (2000) and Staikouras et al. (2008) among others. According to them, the log-linear form is at advantages as it typically improves the regression's goodness of fit and may reduce simultaneity bias.

To investigate the determinants of Islamic bank's efficiency, we construct a model as follow:

$$
\begin{aligned}
T E_{j, t} & =\beta_{1} \sum_{n}^{4} \text { Bank Specifics }_{j, t}+\beta_{2} \sum_{n}^{4} \text { Bank Specifics }_{t} \\
& +\beta_{3} \sum_{n}^{4} \text { Bank Regulation and Supervision }_{t}+\varepsilon_{j, t}
\end{aligned}
$$

Where $T E_{j, t}$ is the technical efficiency, Bank Specifics ${ }_{j, t}$ is a vector of bank specific characteristics, Country Specifics ${ }_{t}$ is a vector of macroeconomic and financial market condition variables, Bank Regulation and Supervision ${ }_{t}$ is a vector to account for Basel II's pillars on bank regulations and supervision, $n$ is number of observation, $\varepsilon_{j, t}$ is the error term, and the subscripts ' $j$ ' and ' $t$ ' represent individual financial institutions and time period, respectively.

Expanding the Model 1, we are going to estimate regression models, which are:

$$
\begin{aligned}
(\mathrm{TE})_{\mathrm{j}, \mathrm{t}} & =\alpha+\beta 1 \ln (\text { EQASS })_{\mathrm{j}, \mathrm{t}}+\beta 2 \ln (\text { LOANSTA })_{\mathrm{j}, \mathrm{t}} \\
& +\beta 3 \ln (\mathrm{TA})_{\mathrm{j}, \mathrm{t}}+\beta 4 \ln (\mathrm{NIETA})_{\mathrm{j}, \mathrm{t}}+\Upsilon 1 \ln (\mathrm{GDP})_{\mathrm{j}, \mathrm{t}} \\
& +\Upsilon 2 \ln (\mathrm{INFL})_{\mathrm{j}, \mathrm{t}}+\Upsilon 3 \ln (\mathrm{CR} 3)_{\mathrm{j}, \mathrm{t}} \\
& +\Upsilon 4 \ln (\mathrm{Z}-\mathrm{SCORE})_{\mathrm{j}, \mathrm{t}}+\delta 1 \ln (\mathrm{SPOWER})_{\mathrm{j}, \mathrm{t}} \\
& +\delta 1 \ln (\mathrm{LCAPRQ})_{\mathrm{j}, \mathrm{t}}+\delta 1 \ln (\mathrm{LACTRS}) \mathrm{j}, \mathrm{t} \\
& +\delta 1 \ln (\mathrm{LPRIMON})_{\mathrm{j}, \mathrm{t}}+\varepsilon_{\mathrm{j}, \mathrm{t}}
\end{aligned}
$$

\subsection{Description of Variables Used in the Panel Regression Models}

We include four bank-specific and four macroeconomic condition variables in the panel regression analysis. To address the issue whether country regulation and supervision matters for bank efficiency, we re-estimate equation (2) to include the four dimensions of country bank regulation and supervision indicators.

\subsection{Bank Specific Characteristic Variables}

We include the natural logarithm of the EQASS (Equity over Total Assets) variable in the regression models to examine the relationship between Islamic bank's efficiency and capitalization. The ratio measures the degree of risk taken by bank managers as higher leverage increase the risk of insolvency, which could result in greater borrowing cost (Berger \& Mester, 1997). Moreover, higher level of capitalization may reflect higher incentives from the stockholders to monitor management, thus resulting in alleviating the efficiency problem caused by conflicts of interest (Eisenbeis et al., 1999). The LOANSTA (Loans to Total Assets) ratio is to account for the level of liquidity, which proxies for differences in bank assets. Liquid assets reduce banks' liquidity risk; however, banks have to incur an opportunity cost for holding liquid assets. This could hamper their cost efficiency and adversely affect their competitive viability. Therefore, there is expected to have a positive relationship between liquidity and efficiency. Berger and Mester (1997) reported that loan to asset ratio is significantly negatively related to cost efficiency and significantly positively related to profit efficiency. Pasiouras and Kosmidou (2007) and Kosmidou (2008) among others have found poor expenses management (NIETA) Non-interest expenses to total assets as among the main contributors to poor banks performance. Clearly, efficient cost management is a prerequisite for the improved efficiency of the Islamic banking sectors and Islamic banks have much to gain if they improve their managerial practices. Furthermore, most of the Islamic banking sectors have not reached the maturity level required to link quality effects from increased spending to higher efficiency. Molyneux and Thornton (1992) found a positive relationship and suggest that high profit banks may be appropriated in the form of higher payroll expenditures paid to the more productive human capital.

\subsection{Macroeconomic and Market Condition Variables}

The gross domestic production (GDP) is a macroeconomic variable used to control for local economic condition. It is also expected to capture the implications for bank efficiency stemming from operating in different economic environment, as demand for financial products depends on the level of economic activity. Generally, higher economic growth encourages bank to lend more and permits them to charge higher margins, as well as improving the quality of their assets. Gross domestic product was used as one of macroeconomicspecific factor. The empirical finding by Maudos et al. (2002), who performed cost efficiency analysis, provided evidence that GDP can be negatively associated with bank efficiency. Another important external condition, which may affect the efficiency of banks, is the inflation rate. Perry (1992) states that the effects of inflation on bank performance depend on whether the inflation is anticipated or unanticipated. In the anticipated case, the interest rates are adjusted accordingly resulting in avenues to increase faster than costs and subsequently leading to a positive impact on performance. 
To control for macroeconomic risk, we include the consumer price index growth rate (lnINFL) as a control variable. The impact of inflation on bank performance may be positive if the rate of inflation is anticipated and banks are able to adjust interest rates accordingly resulting in revenues to increase faster than costs. The CR3 variable measured as the concentration ratio of the three largest banks in terms of assets is introduced in the regression model. There are two competing theories exploring the relationship between the level of concentration in the banking industry and bank performance. According to the structure-conduct-performance (SCP) theory, higher concentration boosts bank performance, since more concentration might imply greater market power and ability to generate higher profits. Insolvency risk indicates banks' distance from failure and the probability of risk of insolvency is proxied by the Z-score. Banks insolvency problem reveal the degree of exposure to losses or failure, which will reduce bank capital reserves that could be used to offset adverse shock. Higher values of the Z-score are associated with lower probabilities of failure or more stable bank whereby lower values Z- score implies a riskier bank. Thus, the more volatile the asset returns, the lower the Z-score.

\subsection{Regulation and Supervision Variables}

We introduce the four country regulation and supervision indicators. To measure the impact of supervisory power, capital requirement, activity restrictions, and private monitoring, variables are included in regression model 2. Theoretical studies have emphasized the relative importance of supervisory power toward the banks' performance. Official supervision can reduce market failure by monitoring and disciplining banks, thus weakening corruption in bank lending and improving the functioning of banks as intermediaries (Beck et al., 2006). Nevertheless, powerful supervisors may exert a negative influence on bank performance. There are many studies that give contradictory empirical results between the bank performance and the official supervisory power. The study by Barth et al. (2004) indicates that there is no strong association between bank development and performance and official supervisory power. However, the results of Barth et al. (2002) show that the more powerful government supervisors are associated with higher levels of non-performing loans, while the results of Pasiouras et al. (2006) also indicate a negative relationship between supervisory power and overall bank soundness.

Theoretically, Barth et al. (2006) mentioned that the capital adequacy requirements prompt bank to be more careful in lending, and it considers as a buffer against losses and consequently, protects banks form failure. On another hand, Barth et al. (2008) argued that, although many countries strengthen capital regulations based on Basel guidelines, the banking system's stability and efficiency were not affected, but in some cases affected negatively as a result of banks shifting toward risky behavior. However, Barth et al. (2013) found a significant positive relationship between capital requirements and banks' efficiency, which suggest that the higher capital stringency the higher banks' efficiency. Moreover, Pasiouras et al. (2009) found a significant and negative relationship between capital requirement and cost inefficiency, and positive relationship between capital requirements and profit inefficiency. They argued that increasing in cost efficiency of the bank due to the increasing of cost of capital, and reduction of profit efficiency resulting from replacement loans with another type of financial assets to meet capital requirements.

Activity Restrictions is an indicator of the degree of which banks may engage in real-estate investment, insurance underwriting and selling, underwriting, brokering and dealing in securities and all aspects of the mutual fund industry. A recent finding by Barth et al. (2010), who conducted a non-parametric frontier analysis based on an international sample of 4,050 bank observations operating in 72 countries during 19992007 , indicates that tighter restrictions on bank activities also exert a negative impact on bank efficiency, while greater capital restrictions are marginally and positively associated with bank efficiency. The evidence broadly supports the role of market discipline. The findings by Chortareas et al. (2011) in their study of commercial banks efficiency on a sample of 22 EU countries over the 20002008 period employing DEA technique, also support the above studies when they also provide supporting evidence that restricting banks from engaging in security activities is strongly associated with lower bank efficiency (Bakri et al., 2018). Private monitoring is measured as the degree of information that is released to officials and the public, auditing-related requirements and whether credit ratings are required (Al-Lamy et al., 2018). According to Barth et al. (2006, 2004), private monitoring by the government can significantly enhance the bank efficiency. This is supported by Pasiouras (2008) who showed that encouraging and facilitating private monitoring of banks could increase efficiency. Demirguc-Kunt and Levine (1999) point out that an underdeveloped financial system is much less likely to have high accounting standards. Barth et al. (2004) also find that regulations that encourage and facilitate private monitoring of banks are associated with greater bank development, lower net interest margins and small non-performing loans. 


\section{Empirical Results}

\subsection{Efficiency of Islamic Banks in MENA Countries}

MENA countries are important because they link Asia to Europe and include Arab oil-rich countries as well as it is a fast-growing region in terms of population and wealth, and they are seeking to improve the efficiency of their financial and monetary performance (Olson \& Zoubi, 2011). The summary of technical efficiency estimates by year for Islamic banking sectors in MENA countries are presented in Tables 2. It is interesting to find that the average technical efficiency in Bahrain, Egypt, Iran, Jordan, Kuwait, Qatar, Saudi Arabia and UAE are among the high average of technical efficiency in this region, standing higher at $70.2 \%, 85.5 \% .67 .7 \%, 54.9 \%$, $50.8 \%, 68.3 \%, 51.3 \%$, and $50.3 \%$, respectively. If anything could be delved, the empirical findings seem to suggest that banks in these countries have been relatively efficient in functioning as an intermediary between savers and borrowers and also efficient in generating revenues by augmenting their deposit base (output). It is observed that the Islamic banking sector in Egypt recorded the highest average of technical efficiency estimates $(85.5 \%)$ with average efficiency scores ranges between $74.6 \%$ (2005) and $71.2 \%$ (2010).

On the other hand, in Tunisia, average efficiency score ranges between $66.7 \%$ (2004) and $30.6 \%$ (2010) with an average equal to $31.8 \%$ over the period of analysis. Thus, the Tunisian Islamic banks could improve their technical efficiency by $68.2 \%$ on average or, in other words, the banks could have used only $31.8 \%$ of the resources actually employed to produce the same level of outputs. This result clearly indicated that the Islamic banking sectors in Tunisia are not relatively good at using the minimum level of inputs at a given level of outputs. Illustratively, none of the Islamic banks operating in these countries are operating at efficient levels. Overall, the empirical findings clearly bring forth that the high degree of inefficiency of the MENA Islamic banking sectors during the period under study mostly stemmed from under-utilization of resources (waste of inputs). Therefore, any empirical examination of the performance of the MENA countries Islamic banking sectors would need to take cognizance of the presence of inefficiency.

The empirical findings reveal that Egypt's Islamic banks could improve their technical efficiency by $14.5 \%$ on average or, in other words, the banks could have used only $85.5 \%$ of the resources actually employed to produce the same level of outputs. The drop marked clearly the years: 2004, 2005, and 2006. The economic environment in these years was characterized by high inflation, which may have caused fluctuations and instability in factor prices. Add also to that the increase in risk appetite as reflected by the big expansion in credit. Moreover, banks have also invested heavily in technology during the period, and this may have forced efficiency to drop. The efficiency level reached $84 \%$ in 2006.

The empirical results indicate a large asymmetry between countries regarding their technical efficiency levels. In Turkey, average efficiency score ranges between $41 \%$ (2005) and $23.6 \%$ (2010) with an average equal to $37.5 \%$ over the period of analysis. Thus, Turkey's Islamic banks could improve their technical efficiency by $62.5 \%$ on average or in other words, the banks could have used only $37.5 \%$ of the resources actually employed to produce the same level of outputs.

Table 2: Technical Efficiency Analysis : MENA Countries

\begin{tabular}{|l|c|c|c|c|c|c|c|c|}
\hline & \multicolumn{7}{|c|}{ Technical Efficiency } & $\begin{array}{c}\text { Average } \\
\text { Efficiency }\end{array}$ \\
\hline Countries/Year & $\mathbf{2 0 0 4}$ & $\mathbf{2 0 0 5}$ & $\mathbf{2 0 0 6}$ & $\mathbf{2 0 0 7}$ & $\mathbf{2 0 0 8}$ & $\mathbf{2 0 0 9}$ & $\mathbf{2 0 1 0}$ & $\mathbf{2 0 0 4 - 2 0 1 0}$ \\
\hline Bahrain & 0.924 & 0.825 & 0.734 & 0.722 & 0.551 & 0.647 & 0.509 & 0.702 \\
\hline Egypt & 1 & 0.996 & 1 & 0.862 & 0.669 & 0.746 & 0.712 & 0.855 \\
\hline Iran & 0.898 & 0.781 & 0.814 & 0.806 & 0.595 & 0.461 & 0.387 & 0.677 \\
\hline Jordan & 0.926 & 0.677 & 0.669 & 0.534 & 0.219 & 0.546 & 0.269 & 0.549 \\
\hline Kuwait & 0.956 & 0.643 & 0.406 & 0.432 & 0.383 & 0.386 & 0.348 & 0.508 \\
\hline Qatar & 0.9135 & 0.515 & 0.709 & 0.766 & 0.641 & 0.614 & 0.621 & 0.683 \\
\hline Saudi Arabia & 1 & 0.443 & 0.599 & 0.472 & 0.533 & 0.273 & 0.274 & 0.513 \\
\hline Sudan & 0.427 & 0.288 & 0.424 & 0.343 & 0.147 & 0.389 & 0.309 & 0.332 \\
\hline Tunisia & 0.667 & 0.235 & 0.297 & 0.219 & 0.197 & 0.306 & 0.306 & 0.318 \\
\hline UAE & 0.754 & 0.3553 & 0.544 & 0.529 & 0.481 & 0.382 & 0.478 & 0.503 \\
\hline Yemen & 0.247 & 1 & 0.103 & 0.083 & 0.256 & 0.513 & 0.412 & 0.373 \\
\hline
\end{tabular}


Table 3: Panel Regression Analysis: MENA Countries

\begin{tabular}{|c|c|c|c|}
\hline & Pooled OLS & Fixed Effect & Random Effect \\
\hline Constant & $\begin{array}{l}1.0348 \\
(0.67)\end{array}$ & $\begin{array}{c}60.9461^{* * *} \\
(5.01)\end{array}$ & $\begin{array}{c}0.7722 \\
(0.33)\end{array}$ \\
\hline Lloansta & $\begin{array}{c}0.1687^{* * *} \\
(4.94)\end{array}$ & $\begin{array}{c}0.0774 \\
(1.55)\end{array}$ & $\begin{array}{c}0.1489^{* * *} \\
(3.66)\end{array}$ \\
\hline Leqass & $\begin{array}{c}-0.0643 \\
(-1.10) \\
\end{array}$ & $\begin{array}{c}0.2064^{*} \\
(1.86) \\
\end{array}$ & $\begin{array}{c}0.0448 \\
(0.59) \\
\end{array}$ \\
\hline Lnieta & $\begin{array}{c}-0.2117^{* * *} \\
(-3.84)\end{array}$ & $\begin{array}{c}-0.1618^{* *} \\
(-2.24)\end{array}$ & $\begin{array}{c}-0.2533^{* * *} \\
(-4.10)\end{array}$ \\
\hline Lnta & $\begin{array}{c}0.0412^{* *} \\
(2.16)\end{array}$ & $\begin{array}{c}0.1700^{*} \\
(1.76)\end{array}$ & $\begin{array}{l}0.0006 \\
(0.02)\end{array}$ \\
\hline Linfl & $\begin{array}{c}-0.1827^{* * *} \\
(-4.25)\end{array}$ & $\begin{array}{c}-0.0859^{*} \\
(-1.91)\end{array}$ & $\begin{array}{c}-0.1706^{* * *} \\
(-4.08)\end{array}$ \\
\hline Lngdp & $\begin{array}{c}-0.0799^{* *} \\
(-1.98)\end{array}$ & $\begin{array}{c}-2.4918^{* * *} \\
(-5.13)\end{array}$ & $\begin{array}{l}-0.0865 \\
(-1.27)\end{array}$ \\
\hline Lcr3 & $\begin{array}{l}-0.1478 \\
(-0.79)\end{array}$ & $\begin{array}{c}-0.1493 \\
(-0.43)\end{array}$ & $\begin{array}{c}0.1074 \\
(0.42)\end{array}$ \\
\hline Lzsore & $\begin{array}{c}0.0954 \\
(1.31)\end{array}$ & $\begin{array}{c}-0.2147^{*} \\
(-1.67)\end{array}$ & $\begin{array}{c}-0.0910 \\
(-0.95)\end{array}$ \\
\hline Lspower & $0.156^{* *}$ & 0654 & $0.303^{*}$ \\
\hline Lcaprq & $\begin{array}{l}0.070 \\
(1.82) \\
\end{array}$ & $\begin{array}{l}0.040 \\
(1.20) \\
\end{array}$ & $\begin{array}{l}0.127 \\
(3.40) \\
\end{array}$ \\
\hline Lactrs & $\begin{array}{l}0.398 \\
(1.82)\end{array}$ & $\begin{array}{l}0.181 \\
(0.88)\end{array}$ & $\begin{array}{l}1.261 \\
(2.20)\end{array}$ \\
\hline Lprimon & $\begin{array}{l}0.895^{*} \\
(2.31)\end{array}$ & $\begin{array}{l}0.0170 \\
(0.06)\end{array}$ & $\begin{array}{l}0.425^{*} \\
(1.26)\end{array}$ \\
\hline Imenalspower & $\begin{array}{c}0.0526 \\
(1.29)\end{array}$ & $\begin{array}{c}-0.0381 \\
(-0.12)\end{array}$ & $\begin{array}{c}0.0441 \\
(0.63)\end{array}$ \\
\hline Imenalcaprq & $\begin{array}{l}-0.0527 \\
(-0.96) \\
\end{array}$ & $\begin{array}{l}0.0850 \\
(0.74) \\
\end{array}$ & $\begin{array}{c}-0.1693^{* *} \\
(-2.30)\end{array}$ \\
\hline Imenalactrs & $\begin{array}{l}0.0050 \\
(0.13)\end{array}$ & $\begin{array}{c}-0.0708 \\
(-0.29)\end{array}$ & $\begin{array}{c}-0.0378 \\
(-0.55) \\
\end{array}$ \\
\hline Imenalprimon & $\begin{array}{c}0.0406 \\
(0.83)\end{array}$ & $\begin{array}{c}0.1734 \\
(0.32)\end{array}$ & $\begin{array}{c}0.0012 \\
(0.01)\end{array}$ \\
\hline BP-LM & $140.20^{* * *}$ & - & - \\
\hline Hausman & - & - & $75.15^{\star \star \star}$ \\
\hline $\mathrm{R}^{2}$ & 0.2850 & 0.0117 & 0.2420 \\
\hline Adjusted $\mathrm{R}^{2}$ & 0.2693 & - & - \\
\hline Root MSE & 0.7187 & - & - \\
\hline F-statistic & $18.16^{\star * *}$ & $8.31^{* * *}$ & - \\
\hline Wald Chi Square & - & - & $60.86^{* * *}$ \\
\hline No of observation & 420 & 420 & 420 \\
\hline
\end{tabular}

* Note Value in parenthesis () are t statistic except for FE, it is $z$ statistic.

***, ${ }^{* *}$ and * indicates significant at $0.01,0.05$ and 0.10 level respectively 
This result clearly indicated that the Islamic banking sectors in these countries are relatively not good at using the minimum level of inputs at a given level of outputs.

\subsection{Determinants of the Efficiency of Islamic Banking in MENA Region}

The empirical findings presented in Tables 3 clearly suggest that the impact of CAPRQ variable is negative toward the efficiency of the Islamic banks in MENA countries (statistically significant at the 5\% level in the Random Effect regression model). The results imply that the capital requirement statistically has a negative impact on the efficiency of Islamic banks that are operating in the MENA countries. The empirical findings suggest that the Islamic banks that operating in the MENA countries tend to be more efficient if they are given less stricter level of the capital requirement regulations, which is in line with Barth et al. (2004) where they find that, while stringent capital requirements are associated with fewer non-performing loans, capital stringency is not robustly linked with banking sector stability, development or bank performance (as measured by overhead and margin ratios) when controlling for other supervisory-regulatory policies. On a similar vein, Pasiouras et al. (2006) also find a negative relationship between capital requirements and banks' soundness as measured by Fitch ratings.

According to research by IFSB (2015), the largest concentration of Islamic finance assets held in the Middle East is about $72 \%$, followed by other parts of Asia (22\%) and other regions $(6 \%)$. Despite the increasing number of new emerging markets, participation of Islamic banks of other world regions, particularly, Europe, remains low. In Asian region, the Shariah boards are considered somewhat less strict in South Asia than in the Middle East (IFSB, 2008). The region has a more developed and experienced conventional banking sector than the MENA region (United Arab Emirates Commercial Banking Report 2009). The income level is slightly lower than the Middle East but higher than North Africa.

\section{Conclusion and Policy Implications}

This study sheds light on the efficiency of Islamic banks by examining the determinants of the efficiency of Islamic banks. We determine the technical efficiency scores of 42 Islamic banks operating in 15 countries across MENA region, and then we regressed the technical efficiency scores as the dependent variable against the bank-specific, country-specific variables and banking regulations and supervision variables in association with Basel II's tenet in order to determine the impact towards the efficiency of Islamic banks during year 2004-2010. The empirical findings clearly bring forth the high degree of inefficiency of the MENA, Asia and other region Islamic banking sectors during the period under study. The findings clearly demonstrate the existence of sizable scale inefficiency among Islamic banks operating in these countries. The findings of the study have very significant implications for regulators, supervisory bodies and policymakers of the banking sector as well as taxpayers (Berger et al., 1991) where the study covered the aspect of challenges and issues pertaining to the regulations and the implications of Basel II framework towards the efficiency of Islamic banks. After highlighting the sources of technical inefficiency of the Islamic banking sectors, we discuss the sources of the scale inefficiency of the Islamic banks in the sample. The empirical findings seem to suggest that in MENA countries, 191 cases of Islamic banks experienced IRS throughout the analyzed years, while 84 cases of Islamic banks in MENA countries experienced diseconomies of scale (DRS).

BCBS acknowledges the fact that commercial real estate is a common source of major credit problems for banks around the world (Sharif et al., 2018). The Shariah principles have meant that Islamic banks have stable deposit bases, no exposure to toxic assets and little leverage, thus, these criteria have shielded the Islamic banks from the worst of the financial crisis (Bakri et al., 2015).

Our findings support the views expressed during both the recent global financial crisis and the Asian crisis regarding the moral hazard issues related to weak private sector monitoring of the financial markets by rating agencies and private investors that leads to the decreasing in the efficiency levels of the banks (Bakri et al., 2016). Moreover, external rating agencies can play a key role in stimulating private monitoring by supplying information to depositors on the quality of the banks (Ali et al., 2015). In a nutshell, we conclude that the stricter the supervisory power, the less strict capital requirement, the tighter the restrictions on nonbanking activities, and the stricter the private monitoring could statistically significantly enhance the level of efficiency of Islamic banks.

\section{References}

Alam, N., \& Al-Amri H. A (2020). Service Quality Perception and Customer Satisfaction in Islamic Banks of Oman. Journal of Asian Finance, Economics and Business, 7(9), 499-504. https:// doi.org/10.13106/jafeb.2020.vol7.no9.499

Ali, R., Ismail, S., \& Bakri, M. (2015). Proposed Islamic educational loan-backed securities for quality life of university graduates in Malaysia. Procedia-Social and Behavioral Sciences, 201, 85-92. https://doi.org/10.1016/j.sbspro.2015.08.134

Al-Lamy, H. A., Bakry, M. H., Raad, W., Al-Shami, S. A., Alaraji, Z. J., Alsa-Lihi, M. W., \& Al-Tameemi, H. M. (2018). Information technology infrastructure and small medium enterprises' in iraq. Opcion, 34(86), 1711-1724 
Banker, R. D., Charnes, A., \& Cooper, W. W. (1984). Some models for estimating technical and scale inefficiencies in data envelopment analysis. Management Science 30, 78-92. https:// doi.org/10.1287/mnsc.30.9.1078

Bakri, M. H., Ali, R., \& Ismail, S. (2016). Developing Primary Market Spread and Measuring Financial Performance of Staff Housing Government Loans. Proceedings of the 1st AAGBS International Conference on Business Management (pp.501511). https://doi.org/10.1007/978-981-287-426-9_44

Bakri, M. H., Ali, R., \& Ismail, S. (2015). The Study of Residential Mortgage Backed Securities During Subprime Mortgage: Malaysian Experience. Advanced Science Letters, 21(5), 1468-1472. https://doi.org/10.1166/asl.2015.6073

Bakri, M. H., Sufian, F, Baharom, A. H., \& Ismail, S (2018). Determinant Of Securitization Spread In Malaysia. International Journal of Business and Society, 19(3), 904-917.

Bakri, M. H., Dabas, N., Ismail, S., \& Hamid, B. A. (2017). Islamic student financing back securitization in Malaysia. Advanced Science Letters, 23, 9, 8090-8093. https://10.1166/ asl.2017.9841

Barth, J. R., Dopico, L. G., Nolle, D. E., \& Wilcox, J. A. (2002). Bank Safety and Soundness and the Structure of Bank Supervision: A Cross-Country Analysis, International Review of Finance, 3(3/4), 163-188. https://doi.org/10.1111/j.1369412X.2002.00037.X

Barth, J. R., Caprio, G., \& Levine, R. (2004). Bank regulation and supervision: what works best? Journal of Financial Intermediation. https://doi.org/13:205-248. 10.3386/w9323

Barth, J. R, Caprio, G. Jr., \& Levine, R. (2006). Rethinking Bank Regulation: Till Angels Govern, Cambridge University Press. https://doi.org/10.1017/CBO9780511753817

Barth, J. R., Caprio, G., \& Levine, R. (2008). Bank regulations are changing: For better or worse. Comparative Economic Studies, 50(4), 537-563. https://doi.org/10.1057/ces.2008.33

Barth, J. R., Liy,A.T and Luy D.W. (2010): Bank Regulation in the United States, CESifo. Economic Studies, 56(1), 112-140. https://doi.org/10.1093/CESIFO/IFP026

Barth, J. R., Caprio Jr, G., \& Levine, R. (2013). Bank Regulation and Supervision in 180 Countries from 1999 to 2011. Journal of Financial Economic Policy, 5(2), 111-219. https://doi. org/10.1108/17576381311329661

Beck, T., Demirguc-Kunt, A., \& Levine, R. (2006). Bank concentration, competition, and crises: First results. Journal of Banking and Finance, 30(5), 1581-1603. https://doi. org/10.1016/j.jbankfin.2005.05.010

Berger, A.N., \& Humphrey, D.B. (1997). Efficiency of Financial Institutions: International Survey and Directions for Future Research. European Journal of Operational Research, 98(2), 175-212. https://doi.org/10.1016/S0377-2217(96)00342-6

Berger, A. N., \& Humphrey, D. B. (1991) The dominance of inefficiencies overscale and product mix economies in banking. Journal of Monetary Economics, 28, 117-148. https://doi. org/10.1016/0304-3932(91)90027-L
Berger, A.N., \& Mester, L.J. (1997). Inside the black box: what explains differences in the efficiencies of financial institutions? Journal of Banking and Finance, 21, 895-947. https://doi. org/10.1016/S0378-4266(97)00010-1

Bitar, M., Walker, T. J., \& Pukthuanthong, K. (2015). Basel III and Bank efficiency: Does one solution fit all? Evidence from Islamic and conventional banks. https://doi.org/ 10.2139/ ssrn.2602198.

Brown, K., \& M. Skully (2005). Islamic Banks: A Cross-Country Study of Cost Efficiency Performance, Accounting, Commerce and Finance. The IslamicPerspective Journal, 8(1-2), 43-79.

Charnes, A., Cooper, W.W., \& Rhodes, E. (1978). Measuring efficiency of decision making units. European Journal of Operations Research, 6, 429-444. https://doi.org/10.1016/03772217(78)90138-8

Chortareas, G., Girardone, C., \& Ventouri, A. (2011). Financial Frictions, Bank Efficiency and Risk: Evidence from the Eurozone. Journal of Business, Finance and Accounting, 38(1-2), 259-287. https://doi.org/10.1111/j.1468-5957.2010. 02226.x

Coelli, T., Prasada, R., \& Battese, G. (1998). An introduction to efficiency and productivity analysis. 2nd ed. New York, NY, United States: Springer.https://doi.org/10.1007/b136381

Demirguc-Kunt, A., \& Huizinga, H. (1999). Determinants of commercial bank interest margins and profitability: some international evidence. World Bank Economic Review, 13, 379-408.

Demirguc-Kunt, A., Laeven, L., \& Levine, R. (2004). Regulations, market structure, institutions, and the cost of financial intermediation. Journal of Money, Credit and Banking, 36, 593-622.

De Bandt, O., \& Davis, E. P. (2000). Competition, contestability and market structure in European banking sectors on the eve of EMU. Journal of Banking and Finance, 24, 1045-66. https:// doi.org/10.1016/S0378-4266(99)00117-X

Duong, T. T. N, Phan, H. T, Hoang, T. N., \& Von, T.T.T (2020). The Effect of Financial Restructuring on the Overall Financial Performance of the Commercial Banks in Vietnam. Journal of Asian Finance, Economics and Business, 7(9), 075-084. https:// doi.org/10.13106/jafeb.2020.vol7.no9.075

Farrell, M. J. (1957). The measurement of productive efficiency. Journal of Royal Statistical Society Association, 120, 253-281. https://doi.org/10.2307/2343100

Haron, S. (2004). Determinants of Islamic Banking Profitability. Global journal of Finance and Economics, 28, 314-337.

Hassan, M. K. (2005). The Cost, Profit and X-Efficiency of Islamic Banks: Economic Research Forum, 12th Annual Conference, Cairo, Egypt.

Hassan, M. K., \& Bashir, A. H. (2005). Determinants of Islamic Banking Profitability, in Munawar Iqbal and Rodney Wilson (eds), Islamic Perspectives on Wealth Creation. Edinburgh: Edinburgh University Press. DOI:10.3366/ edinburgh/9780748621002.003.0008 
Hassan, M. K., \& Hussein, K. A. (2003). Static and Dynamic Efficiency in the Sudanese Banking System. Review of Islamic Economics, 14, 5-48.

Idris, N. H., Yazid, Z. A., Faique, F. A., Daud, S., Ismail, S., Bakri, M. H., \& Taib, N. M. (2016). Financial literacy and debt burden among Malay youth workers in Malaysia. Advanced Science Letters, 22(12), 4288-4292. https://doi.org/10.1166/ as1.2016.8130

Ismail, S., Bakri, M. H., Ali, R., \& Noor, A. M. (2014). Developing a Framework of Islamic Student Loan-backed Securitization. Procedia-Social and Behavioral Sciences, 129, 380-387. https://doi.org/10.1016/j.sbspro.2014.03.691

Ismail, S., Faique, F. A., Bakri, M. H., Zain, Z. Mc, Idris, N. H., Yazid, Z. A., Daud, S., \& Taib, N. M. (2017). The role of financial self-efficacy scale in predicting financial behaviour. Advanced Science Letter, 23(5), 4635-4639. https://doi. org/10.1166/asl.2017.8992

Isik, I., \& Hassan, M. K. (2002). Cost and profit efficiency of the Turkish banking industry: An empirical investigation. The Financial Review, 37(2), 257-280. https://doi.org/10.1111/15406288.00014

Iqbal, M. (2001). Islamic and conventional banking in the nineties: a comparative study. Islamic Economic Studies, 8, 1-27.

Kosmidou, K. (2008). The determinants of banks' profits in Greece during the period of EU financial integration. Managerial Finance, 34(3), 146-159. https://doi. org/10.1108/03074350810848036

Maudos, J., Pastor, J. M., Francisco, P., \& Javier, Q. (2002). Cost and Profit Efficiency in European Banks. Journal of International Financial Markets, Institutions and Money, 12, 33-58. https:// doi.org/10.1016/S1042-4431(01)00051-8

Molyneux, P., \& Thornton, J. (1992). Determinants of European bank profitability: A note. Journal of Banking and Finance, 16(6), 1173-1178. https://doi.org/10.1016/03784266(92)90065-8

Olson, D. and Zoubi, T.A. (2008). Using accounting ratios to distinguish between Islamic and conventional banks in the GCC region. International Journal of Accounting, 43, 45-65

Pasiouras F., Gaganis C., \& Zopounidis C., (2006). The Impact of Bank Regulations, Supervision, Market Structure and Bank Characteristics on Individual Bank Ratings: A Cross Country
Analysis. Review of Quantitative Finance and Accounting, 27(4), 403-438. https://doi.org/10.1007/s11156-006-0045-0

Pasiouras, F., \& Kosmidou, K. (2007). Factors influencing the profitability of domestic and foreign commercial banks in the European Union. Research in International Business and Finance, 21, 222-237. https://doi.org/10.1016/j.ribaf.2006.03.007

Pasiouras F., Tanna S., \& Zopounidis C., (2009). The Impact of Banking Regulations on Banks' Cost and Profit Efficiency: Cross-Country Evidence. International Review of Financial Analysis, 18(5), 294-302. https://doi.org/10.1016/j.irfa.2009. 07.003

Perry, P. (1992). Do Banks Gain or Lose from Inflation. Journal of Retail Banking, 14 (2), 25-40.

Samad, A., \& M. K. Hassan (1999). The Performance of Malaysian Islamic Bank during 1984-1997: An Exploratory Study. International Journal of Islamic Financial Services, 1(3), 1-14. http://dx.doi.org/10.2139/ssrn.3263331

Sealey, C., \& Lindley, J.T. (1977). Inputs, outputs and a theory of production and cost at depository financial institutions. The Journal of Finance, 32, 1251-1266. https://doi. org/10.1111/j.1540-6261.1977.tb03324.x

Sharif, S. M, Nizam, N. Z, Rashid, N. A, Masrom, N. R., \& Bakri, M. H. (2018). Role of Values and Competencies in University Intellectual Property Commercialization: A Critical Review. The Turkish Online Journal of Design, Art and Communication, 887-904. https://doi.org/10.7456/1080SSE/125

Staikouras, C., Mamatzakis, E., \& Koutsomanoli-Filippaki, A. (2008). An empirical investigation of operating performance in the new European banking landscape. Global Finance Journal, 19, 32-45

Sufian, F., Kamarudin, F., \& Noor, N. H. H. M. (2012). Determinants of revenue efficiency in the Malaysian Islamic banking sector. Journal of King Abdul Aziz University: Islamic Economics, 25, 195-224. https://doi.org//10.4197 / Islec. 25-2.7

Widarjono, A., Hendrie Anto M. B., \& Fakhrunnas, F. (2020). Financing Risk in Indonesian Islamic Rural Banks: Do Financing Products Matter? Journal of Asian Finance, Economics and Business, 7(9), 305-314. https://doi.org/10.13106/jafeb.2020. vol7.no9.305

Yudistira, D. (2004). Efficiency in Islamic Banking: An Empirical Analysis of 18 Banks. Islamic Economic Studies, 12(1), 1-19. 